\title{
CS-30 -Diagnóstico sobre el conocimiento y uso de materiales digitales accesibles por profesores universitarios para la enseñanza
}

\author{
Diagnosis about the knowledge and use of accessible instructional \\ materials by university professors
}

\section{Mario Rubén Ruíz Cornelio*, Guadalupe Palmeros y Ávila, Irma Alejandra Coeto Calcáneo, Sara Margarita Alfaro García, Jacinta Hernández Pérez}

División Académica de Educación y Artes, Universidad Juárez Autónoma de Tabasco, México.

*Autor a quien se dirige la correspondencia: ruizmruben@hotmail.com

\section{Resumen}

$\mathrm{C}_{\mathrm{n}}$ la actualidad los retos en materia educativa han evolucionado, de tal manera que uno de los mayores desafíos - de nuestra época es el de reducir la brecha digital entre los estudiantes con discapacidad y con ello propiciar su inclusión social-digital. Aunque existen políticas tanto nacionales como internacionales que buscan hacer realidad la inclusión educativa de los grupos más vulnerables, todavía hace falta que las personas con discapacidad tengan un pleno acceso a la Educación. Esta accesibilidad involucra no solamente contar con la infraestructura necesaria para la atención de estos grupos vulnerables o acceder a los diversos niveles del sistema educativo mexicano, sino en un contexto más amplio saber diseñar materiales digitales de clase que puedan ser utilizados por todos los estudiantes tengan o no una discapacidad. En esta investigación se dan a conocer los resultados de un diagnóstico efectuado a un grupo de profesores universitarios en el sureste mexicano sobre el conocimiento y uso de materiales digitales accesibles; mediante este estudio se muestran las pautas a seguir para la elaboración de materiales digitales accesibles en beneficio principalmente, aunque no exclusivamente, de los estudiantes con discapacidad visual.

Palabras claves: Educación inclusiva, discapacidad, educación superior, materiales de enseñanza, tecnologías de la información y de la comunicación.

\section{Abstract}

\begin{abstract}
A $\mathrm{t}$ present the challenges in education have evolved, so that one of the greatest challenges of our time is to reduce A the digital breach between students with disabilities and thereby foster their social-digital inclusion. Although there are national and international policies that seek to realize the educational inclusion of the most vulnerable groups, it is still necessary for people with disabilities to have full access to education. This accessibility involves not only having the necessary infrastructure to care for these vulnerable groups or accessing the various levels of the Mexican educational system, but also in a broader context to know how to design accesible instructional materials that can be used by all students, having a disability or not. In this research the results of a diagnosis made to a group of university professors in the Mexican southeast about the knowledge and use of accessible instructional materials are presented. This study shows the guidelines to be followed for the design of accessible instructional materials for the benefit of, but not exclusively, students with visual impairment.
\end{abstract}

Key words: Inclusive education, disabilities, higher education, instructional materials, information and communication technology 